\title{
Neoliberal Governance and Uneven Development in Jersey City
}

\section{Donal Malone ${ }^{1}$}

In 2015, Jersey City was experiencing a new period of growth with a record number of housing units created or in production and thousands more jobs added to its economy. A new and more progressive administration was at the helm announcing that this round of growth would benefit more residents than previous ones, which were largely viewed as benefitting one segment of the population and area of the city. However, despite these assurances, and some efforts toward more shared growth, this new development has been very unevenly and unequally distributed across the city. This is the result of a neoliberal approach to governing that allowed developers and corporations to influence development in their interests to the detriment of most residents. [Article copies available for a fee from The Transformative Studies Institute. E-mail address: journal@transformativestudies.org Website: http://www.transformativestudies.org (C2017 by The Transformative Studies Institute. All rights reserved.]

KEYWORDS: Neoliberalism, Uneven Development, Growth Machine, Gentrification.

In 2015, Jersey City was once again in the midst of a new round of economic development creating more jobs and housing. A news release from the mayor's office described the construction of 6,000 new housing units along with 18,000 underway as, "the greatest construction activity in the City's history." It also noted that the city added 9,000 jobs in construction, small businesses and corporations resulting in a decline in

\footnotetext{
${ }^{1}$ Donal Malone received his Ph.D. in sociology from the Graduate Center of the City University of New York in 1988. The same year he began working at Saint Peters' University in Jersey City in the Sociology and Urban Studies Department where he teaches courses in sociological theory, urban change, and community organizing. His research is focused on urban inequality - its causes, consequences and solutions. Dr. Malone's current research is centered on policies and programs that promote more equitable urban development. Address correspondence to: Dr. Donal Malone, Sociology \& Urban Studies Department, Saint Peter's University, 2641 Kennedy Boulevard, Jersey City, NJ 07306; e-mail: dmalone@saintpeters.edu.
} 